\title{
PENGARUH MODEL PEMBELAJARAN GUIDED INQUIRYTERHADAP HASIL BELAJAR KOGNITIF MATERI SISTEM SARAF MANUSIA
}

Sariningsih ${ }^{1 *}$, Purwati Kuswarini Suprapto ${ }^{1}$, Liah Badriah ${ }^{1}$

${ }^{1}$ Universitas Siliwangi, Jalan Siliwangi No 24 Tasikmalaya, Jawa Barat, Indonesia

* corresponding author | email : sariningsih116@gmail.com

\begin{abstract}
Dikirim 24 September 2019 Diterima 7 Januari $2021 \quad$ Diterbitkan 9 Januari 2021
ABSTRAK doi http://dx.doi.org/10.17977/um052v12i1p1-7

Penelitian ini bertujuan untuk mengetahui pengaruh model pembelajaran guided inquiry terhadap hasil belajar peserta didik di kelas XI MIPA SMA Negeri 1 Sindangkasih pada materi sistem saraf manusia. Penelitian ini dilaksanakan pada bulan September 2018 sampai dengan bulan Juli 2019 di SMA Negeri 1 Sindangkasih. Metode penelitian yang digunakan adalah true experiment. Populasi dalam penelitian ini adalah seluruh kelas XI MIPA SMA Negeri 1 Sindangkasih sebanyak 3 kelas. Sampel yang digunakan sebanyak 2 kelas yaitu kelas XI MIPA 1 sebagai kelas eksperimen dan kelas XI MIPA 3 sebagai kelas kontrol yang diambil dengan teknik cluster random sampling. Teknik pengumpulan data berupa tes tulis hasil belajar pada materi sistem saraf manusia yang dilakukan sebelum dan sesudah pembelajaran berlangsung. Data hasil penelitian dianalisis dengan menggunakan uji ancova. Hasil penelitian menunjukkan bahwa terdapat pengaruh model pembelajaran guided inquiry terhadap hasil belajar peserta didik pada materi sistem saraf manusia di kelas XI MIPA SMA Negeri 1 Sindangkasih.
\end{abstract}

\section{Kata Kunci : Hasil Belajar, Guided Inquiry}

This study aimed to determine the effect guided inquiry learning model toward learning outcomes of students in XI MIPA classes at SMA Negeri 1 Sindangkasih on nervous system subject. This research was conducted from September 2018 until July 2019 at SMA Negeri 1 Sindangkasih. The research used the true experiment method. The population in this study were all XI MIPA at SMA Negeri 1 Sindangkasih as many as 3 classes. The sample used was 2 classes, namely class XI MIPA 1 as the experimental class and class XI MIPA 3 as the control class taken by cluster random sampling technique. Data collection techniques in the form of tests of learning outcomes on the nervous system subject was conducted before and after learning process were taken place. The datas were analyzed by using the Ancova test. The results showed that there was the effect guided inquiry learning model toward learning outcomes of students on nervous system subject in XI MIPA classes at SMA Negeri 1 Sindangkasih.

Keywords : Learning Outcomes, Guided Inquiry

Masyarakat dunia saat ini sedang memasuki era baru yang menyebabkan terjadinya percepatan perubahan dalam berbagai aspek atau bidang termasuk dalam bidang pendidikan. Sehingga permasalahan yang ada dalam dunia pendidikan formal saat ini senantiasa bertambah dan semakin kompleks, karena pendidikan selalu dituntut untuk mengalami kemajuan dari berbagai bidang yang 
salah satunya yaitu sains. Sains merupakan cara mencari tahu tentang alam sekitar secara sistematis. Menurut Badriah, Liah (2016:54) bahwa "Sains berkaitan dengan cara mencari tahu tentang alam sehingga sains bukan hanya penguasaan kumpulan pengetahuan yang berkaitan dengan fakta-fakta, konsep-konsep atau prinsip-prinsip saja tetapi juga merupakan proses penemuan".

Belajar sains tidak cukup hanya menghafal materinya saja tetapi juga harus dapat memahami konsep-konsep didalamnya. Hal ini dapat tercapai jika pembelajaran tersebut bermakna. Menurut Ausubel (Dahar, 2001:137) "Belajar bermakna merupakan suatu proses mengaitkan informasi baru pada konsep relevan dalam struktur kognitif seseorang".

Pengetahuan kognitif dapat diukur salah satunya dengan melihat hasil belajar peserta didik. Jika dalam hasil belajar peserta didik kurang memenuhi kriteria, maka untuk meningkatkan hasil belajar peserta didik dapat dilakukan dengan menggunakan model pembelajaran yang disesuaikan dengan materi yang akan disampaikan, kondisi peserta didik, sarana yang tersedia serta tujuan pengajarannya. Pada kenyatannya sesuai dengan pendapat Liliasari (Taofiq, et.al., 2018:549) "Model pembelajaran sains pada umumnya masih menggunakan pendekatan tradisional yaitu peserta didik dituntut lebih banyak mempelajari konsep-konsep dan prinsip-prinsip sains secara verbalitas".

Berdasarkan hasil observasi kelas XI MIPA SMA Negeri 1 Sindangkasih pada tanggal 4 Desember 2018. Kelas XI MIPA terdiri dari tiga kelas. KKM yang ditetapkan untuk mata pelajaran biologi kelas XI MIPA adalah 75, sedangkan pencapaian nilai beberapa peserta didik rata-rata belum memenuhi standar yang ditentukan. Salah satu penyebab rendahnya KKM tersebut ialah peserta didik yang kurang aktif dan pemahaman pengetahuan terhadap sains dalam proses pembelajaran. Sehingga perlu adanya inovasi perbaikan pengajaran agar hasil belajar peserta didik tercapai.

Salah satu upaya perbaikan yang dapat dilakukan adalah dengan memperbaiki proses pembelajaran di sekolah yang dapat mengkondisikan peserta didik sebagai pusat pembelajaran (student centered) selama kegiatan pembelajaran berlangsung.

Sanjaya \& Kauchak (Taofiq, Muhammad, et.al., 2018:550) mengemukakan bahwa penerapan model pembelajaran inkuiri didasarkan atas beberapa pertimbangan (1) model pembelajaran inkuiri berbasis konstruktivistik, (2) model pembelajaran inkuiri memberikan peluang kepada peserta didik untuk melakukan kegiatan belajar mengajar menggunakan metode ilmiah dalam menyelesaikan masalah, (3) kegiatan pembelajaran terpusat pada peserta didik, (4) model pembelajaran inkuiri terbimbing mengajarkan peserta didik untuk memperoleh pemahaman, (5) model pembelajaran inkuiri menekankan pada proses berpikir secara kritis dan analitis untuk mencari dan menemukan sendiri jawaban dari suatu masalah yang dipertanyakan.

Oleh karena itu, penulis mencoba menerpakan model pembelajaran guided inquiry dijadikan alternatif untuk meningkatkan hasil belajar peserta didik. Model pembelajaran Guided Inquiry, yang menekankan keaktifan peserta didik dalam mencari dan menyelidiki, sesuai dengan sintaks yang dikemukakan menurut Sanjaya (Yani dan Ruhimat, 2018:66) yaitu "Orientasi, merumuskan masalah, merumuskan hipotesis, mengumpulkan data, menguji hipotesis, dan merumuskan kesimpulan". Pada setiap sintaks tersebut dimungkinkan untuk membantu peserta didik dalam mengingkatkan hasil belajarnya.

Materi yang dipakai dalam penelitian ini adalah sistem saraf manusia. Karakteristik materi yang abstrak dan rumit salah satunya karena berhubungan dengan mekanisme fisik dan kimiawi yang kompleks. Sehingga sulit dipahami peserta didik dalam pelaksanaan pembelajarannya.

Sehingga tujuan dalam penelitian ini mengenai pengaruh model pembelajaran Guided Inquiry terhadap hasil belajar peserta didik materi sistem saraf manusia di kelas XI MIPA SMA Negeri 1 Sindangkasih pada tahun ajaran 2018/2019. Dalam penelitian dengan menggunakan model tersebut diharapkan dapat meningkatkan hasil belajar peserta didik pada materi sistem saraf pada manusia.

Sebagai kajian pustaka, bagian ini harus disertai rujukan yang dapat dijamin otoritas penulisnya. Jumlah rujukan harus proposional (tidak terlalu sedikit dan tidak terlalu banyak). Pembahasan kepustakan harus disajikan secara ringkas, padat, dan langsung mengenai masalah yang diteliti. Aspek yang dibahas boleh landasan teorinya, segi historisnya, atau segi lainnya.

Penyajian latar belakang atau rasional hendaknya sedemikian rupa sehingga mengarahkan 
pembaca ke rumusan masalah penelitian yang dilengkapi dengan rencana pemecahan masalah dan akhirnya ke rumusan tujuan. Untuk penelitian kualitatif, di bagian ini dijelaskan juga fokus penelitian dan uraian konsep yang berkaitan dengan fokus penelitian.

\section{METODE}

Populasi dalam penelitian ini adalah seluruh kelas XI MIPA SMA Negeri 1 Sindangkasih tahun ajaran 2018/2019, sebanyak 3 kelas. Sampel dalam penelitian ini diambil dengan menggunakan teknik cluster random sampling yaitu kelas XI MIPA 1 sebagai kelas eksperimen dan kelas XI MIPA 3 sebagai kelas kontrol.

Instrumen penelitian yang digunakan dalam penelitian ini adalah tes tulis hasil belajar sebanyak 30 butir soal berbentuk pilihan majemuk. Tes hasil belajar disusun berdasarkan Taksonomi Bloom yang telah direvisi dengan dimensi kognitif yang meliputi pengetahuan faktual $\left(K_{1}\right)$, pengetahuan konseptual $\left(\mathrm{K}_{2}\right)$, pengetahuan prosedural $\left(\mathrm{K}_{3}\right)$, serta dibatasi pada dimensi kognitif mengingat $\left(\mathrm{C}_{1}\right)$, memahami $\left(C_{2}\right)$, mengaplikasikan $\left(C_{3}\right)$, menganalisis $\left(C_{4}\right)$, dan mengevaluasi $\left(C_{5}\right)$.

Desain penelitian yang digunakan dalam penelitian ini adalah pretest-posttest control group design. Dalam desain ini dua kelompok yang dipilih secara random, diberi pretest untuk mengetahui keadaan awal adakah perbedaan antara kelompok eksperimen dan kelompok kontrol. Peneliti samasama melakukan posttest pada kedua kelompok tersebut, dan hanya kelompok eksperimen saja yang diberi perlakuan. (Sugiyono, 2017:76)

\begin{tabular}{lllll} 
Kelas Eksperimen & $\mathrm{R}$ & $\mathrm{O}_{1}$ & $\mathrm{X}$ & $\mathrm{O}_{2}$ \\
\cline { 2 - 5 } Kelas Kontrol & $\mathrm{R}$ & $\mathrm{O}_{3}$ & & $\mathrm{O}_{4}$
\end{tabular}
Keterangan:
$\mathrm{X}$ : perlakuan (treatment)
$\mathrm{O}_{1}$ : pretest pada kelas eksperimen
$\mathrm{O}_{2}$ : posttest pada kelas eksperimen
$\mathrm{O}_{3}$ : pretest pada kelas kontrol
$\mathrm{O}_{4}$ : posttest pada kelas control
$\mathrm{R}$ : randomisasi

Data analisis dengan menggunakan prasyarat analisis dan uji hipotesis. Uji normalitas dianalisis dengan uji Kolmogorov-smirnov dan uji homogenitas dianalisis dengan uji Levene. Hipotesis dianalisis dengan menggunakan uji Ancova. Keseluruhan analisis data dilakukan dengan menggunakan spss for windows versi 23.

\section{HASIL DAN PEMBAHASAN}

Berdasarkan hasil penelitian dengan data yang diperoleh melalui pretest dan posttest menggunakan instrumen hasil belajar dari kelas eksperimen dan kelas kontrol. Berikut statistik perbandingan yang disajikan dalam Tabel 1.

Tabel 1 memperlilhatkan bahwa kelas eksperimen yang menggunakan model pembelajaran guided inquiry memiliki skor rata-rata lebih tinggi yaitu skor rata-rata pretest 14,34 dan posttest 25,44 dibandingkan skor rata-rata pada kelas kontrol yang menggunakan pembelajaran langsung dengan skor rata-rata pretest 13,47 dan skor posttest 23,63 . Hal ini menunjukkan bahwa model pembelajaran guided inquiry dapat diterima peserta didik sehingga dapat meningkatkan hasil belajar. Berdasarkan hasil uji prasyarat analisis yang telah dilakukan, seluruh data telah memenuhi prasyarat analisis yaitu data berasal dari populasi yang berdistribusi normal dengan variansi yang homogen. 
Jurnal Pendidikan Biologi | Vol. 12, No. 1, Agustus 2020, pp. 1-7

Tabel 1. Statistik Hasil Belajar Peserta Didik di Kelas Eksperimen dan Kelas Kontrol.

\begin{tabular}{lrrrr}
\hline \multirow{2}{*}{ Statistik } & \multicolumn{2}{c}{ Kelas Eksperimen } & \multicolumn{2}{c}{ Kelas Kontrol } \\
\cline { 2 - 5 } Maksimum & Pretest & Posttest & Pretest & Posttest \\
\hline Minimum & 20 & 30 & 18 & 28 \\
\hline Rata-rata & 10 & 22 & 10 & 21 \\
\hline Varians & 14,34 & 25,44 & 13,47 & 23,63 \\
\hline Standar deviasi & 8,491 & 6,319 & 5,354 & 4,758 \\
\hline
\end{tabular}

Setelah data telah memenuhi prasyarat analisis, maka dilakukan pengujian hipotesis dengan uji ancova. Hasil uji Ancova bahwa angka signifikansi untuk corrected model adalah 0,000 karena nilai Sig. 0,05 maka Ho ditolak. Hal ini berarti pada tingkat kepercayaan 95\% dapat dikatakan ada pengaruh model pembelajaran guided inquiry terhadap pretest dengan skor hasil belajar peserta didik. Pernyataan ini mengindikasikan bahwa asumsi ancova telah terpenuhi. Selanjutnya dilakukan pengujian untuk mengetahui pengaruh model pembelajaran terhadap skor hasil belajar, pengujian ini dilakukan dengan menghilangkan pegaruh pretest dari model. Dari hasil pengolahan terlihat bahwa angka signifikansi model pembelajaran adalah 0,000 . Karena nilainya $<0,05$ maka Ho ditolah. Sehingga tingkat kepercayaan $95 \%$ dapat disimpulkan bahwa model pembelajaran berpengaruh terhadap skor hasil belajar peserta didik.

Untuk mengetahui pengaruh pretest dan model pembelajaran guided inquiry terhadap nilai hasil belajar peserta didik, dapat dilihat dari angka signifikansi sebesar 0,000. Karena nilainya $<0,05$ maka Ho ditolak. Sehingga dapat disimpulkan bahwa pretest dan model pembelajaran berpengaruh terhadap skor hasil belajar peserta didik.

Adapun data hasil penelitian terlihat dari perbandingan rata-rata skor pretest, posttest, dan $\mathrm{N}$ gain hasil belajar peserta didik pada kelas eksperimen dan kelas kontrol yang disajikan dalam diagram pada Gambar 1.

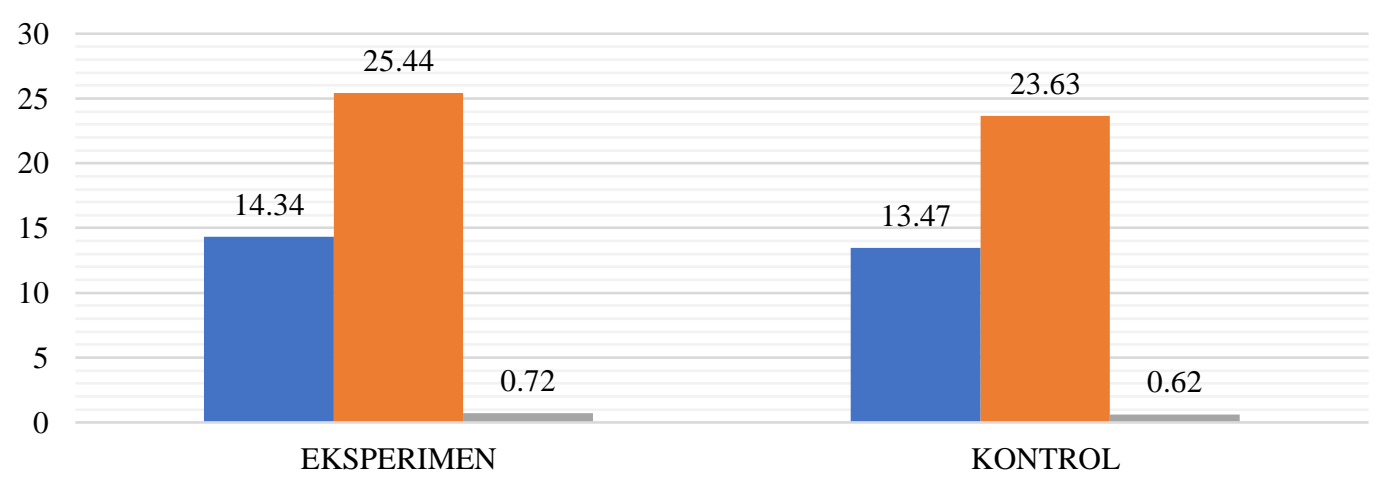

Gambar 1. Diagram Perbandingan Skor pretest, posttets dan $\mathbf{N}$-gain Kelas Eksperimen dan Kelas Kontrol

Gambar 1 memperlihatkan bahwa skor rata-rata pretest di kelas eksperimen adalah 14,34 dan posttest 25,44 dengan $\mathrm{N}$-gain 0,72 termasuk kategori tinggi. Sedangkan untuk kelas kontrol skor ratarata pretest 13,47 dan posttest 23,63 dengan $N$-gain 0,62 yang termasuk dalam kategori sedang. Hal ini disebabkan karena model pembelajaran yang berorientasi pada peserta didik (student centered) sehingga guru bukan lagi sebagai sumber informasi. Melainkan peserta didik yang aktif dalam menemukan konsep-konsep terkait materi pembelajaran sehingga memotivasi peserta didik dalam memecahkan permasalahan yang dapat meningkatkan hasil belajarnya. Hal ini sejalan menurut Partono dan Ngasarotur (2015:71) menyebutkan bahwa "model pembelajaran inkuiri terbimbing berpengaruh signifikan terhadap hasil belajar peserta didik".

Hal ini membuktikan bahwa skor rata-rata kelas eksperimen lebih besar dibandingkan dengan skor rata-rata kelas kontrol, dikarenakan pada model pembelajaran guided inquiry peserta didik terlibat aktif pada proses berpikir, membangun dan menemukan konsep sendiri berdasarkan masalah 
yang dikaji. Sejalan dengan penelitian yang dilakukan oleh Iswatun, et.al., (2017:157) menjelaskan bahwa "model pembelajaran guided inquiry lebih efektif meningkatkan hasil belajar kognitif siswa. Hal ini dikarenakan, model pembelajaran guided inquiry memusatkan pembelajaran pada peserta didik dalam menyatukan konstruksi pengetahuan dalam pembelajaran kehidupan sehari-hari". Sehingga dalam kegiatan diskusi dengan teman, mempelajari hal berbeda, serta menganalisis suatu permasalahan yang dikaji dapat melatih keterampilan peserta didik.

Adapun berdasarkan perolehan skor $\mathrm{N}$-gain kelas eksperimen dan kelas kontrol pada hasil belajar peserta didik untuk setiap dimensi kognitif, dapat dilihat pada diagram berikut ini (Gambar 2).

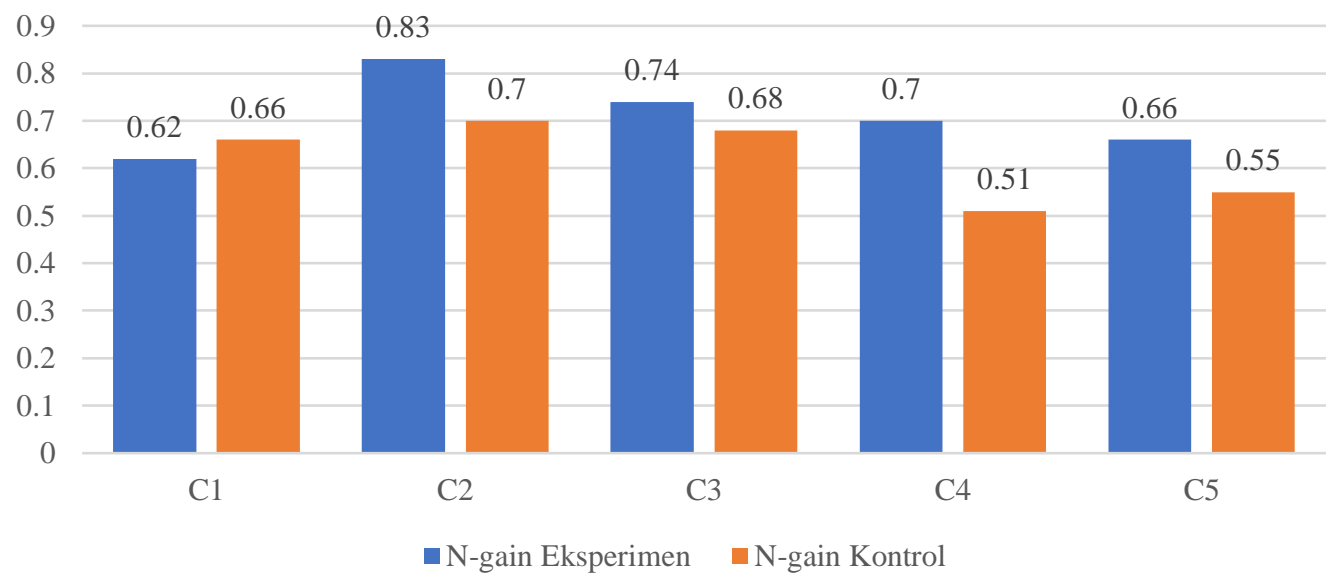

\section{Gambar 2. Diagram Perbandingan Skor $\mathbf{N}$-gain Kelas Eksperimen dan Kelas Kontrol untuk Setiap Dimensi Kognitif}

Berdasarkan Gambar 2 memeperlihatkan bahwa pada kelas eksperimen yang menggunakan model pembelajaran guided inquiry mampu meningkatkan dimensi kognitif C2 (memahami), C3 (mengaplikasikan), C4 (menganalisis), dan C5 (mengevaluasi). Sedangkan pada kelas kontrol dimensi kognitif $\mathrm{C} 1$ (mengingat) lebih tinggi dibandingkan dengan kelas eksperimen, dikarenakan dalam proses pembelajaran direct instruction peserta didik menerima materi dari guru secara verbal kemudian diberikan tugas untuk pengerjaan LKPD. Sehingga peserta didik mampu mengingat materi yang dipelajarinya.

Maka dapat disimpulkan bahwa skor rata-rata $\mathrm{N}$-gain dimensi kognitif hasil belajar peserta didik di kelas eksperimen lebih baik dibandingkan kelas kontrol, karena model pembelajaran guided inquiry melibatkan peserta didik untuk mencari dan menemukan konsep sendiri. Perbandingan skor rata-rata $\mathrm{N}$-gain yang terlihat antara kelas eksperimen dan kelas kontrol, pada dimensi kognitif C2 (memahami) dan C4 (menganalisis). Meningkatnya kemampuan memahami dan menganalisis termasuk aspek yang mendapatkan skor paling tinggi di kelas eksperimen, Hal ini disebabkan karena dalam proses pembelajaran guru menuntut peserta didik untuk menemukan sendiri konsep yang dipelajari sehingga peserta didik harus mengonstruk pemahamannya sendiri. Selain itu, dalam menganalisis suatu permasalahan peserta didik perlu menganalisa dulu permasalahan mengenai sistem saraf. Oleh karenanya, menurut Slavin (Bagiarta, N., et.al., 2015:3) "Model pembelajaran guided inquiry merupakan model pembelajaran kooperatif menggalakan siswa berinteraksi secara aktif dan positif dalam kelompok".

Pada kelas kontrol yang menggunakan model pembelajaran direct instruction skor rata-rata $\mathrm{N}$ gain pada dimensi kognitif C1 (mengingat) sebesar 0,66 termasuk kategori sedang, lebih tinggi dibandingkan kelas eksperimen. Hal ini terjadi karena pada proses pembelajaran guru menyampaikan materi terlebih dahulu dan dilanjutkan dengan sesi tanya jawab, sehingga peserta didik cenderung mudah mengingat penyampaian dari guru. Selain itu, melalui pengerjaan LKPD menuntut peserta didik untuk mengingat kembali apa yang telah disampaikan guru agar dapat menjawab pertanyaan yang disajikan dalam LKPD. 
Model pembelajaran Guided Inquiry merupakan suatu model pembelajaran berbasis penyelidikan, model ini juga mengajarkan peserta didik dalam penemuan atas konsep materi yang dilakukan dengan cara diskusi untuk mencari solusi pemecahan masalah dalam rangka mencapai tujuan pembelajaran. Didukung dengan pernyataan Dimyati dan Mudjiono (Nurfausiah, 2016:11) "inkuri termbimbing (guided inquiry) merupakan salah satu model pembelajaran inkuiri yang dirancang untuk mengajarkan konsep-konsep atau hubungan anatar konsep". Model pembelajaran guided inquiry juga berorientasi pada peserta didik, sehingga guru hanya sebagai fasilitator. Penerapan model pembelajaran Guided Inquiry ini, peserta didik secara alami bekerja sama untuk memecahkan suatu permasalahan, aktif dalam proses pembelajaran, mampu membina peserta didik untuk dapat meningkatkan hasil belajar peserta didik.

Berdasarkan hasil penelitian yang menggunakan model pembelajaran guided inquiry membuat suasana pembelajaran menjadi lebih aktif sehingga memotivasi dirinya untuk mencari jawaban terhadap permasalahan dan peserta didik tidak lagi menjadikan pendidik sebagai satu-satunya sumber informasi. Hal ini didukung dengan pendapat Sanjaya (Amijaya, et.al., 2018:96) yang menyebutkan bahwa model guided inquiry memiliki beberapa kelebihan yaitu pembelajaran yang menekankan kepada pengembangan aspek kognitif, afektif dan psikomotor secara seimbang, memberikan ruang kepada peserta didik untuk belajar sesuai dengan gaya belajar mereka, dan peserta didik yang memiliki kemampuan belajar bagus tidak akan terhambat oleh peserta didik yang lemah dalam belajar.

Selain memiliki kelebihan pada model pembelajaran guided inquiry tentunya ada kekurangan yang ditermukan pada saat penelitian berlangsung yaitu membutuhkan waktu yang cukup lama. Sejalan dengan Kuhlthau (Nurdiansyah dan Fahyuni, 2016:148) "proses pembelajaran guided inquiry membutuhkan waktu yang lebih lama". Selain itu kendala yang ditemukan ketika proses pembelajaran berlangsung pendidik sulit mengontrol kegiatan dan keberhasilan peserta didik jika di kelas yang diajarkan memiliki jumlah peserta didik yang cukup banyak. Setiap peserta didik memiliki karakteristik berbeda-beda, sehingga tidak semua peserta didik mampu untuk menerima proses pembelajaran ini.membutuhkan stimulus yang baik agar peserta didik memiliki keinginan untuk berperan aktif dalam pembelajaran.

\section{KESIMPULAN DAN SARAN}

\section{Kesimpulan}

Penelitian ini bertujuan untuk mengetahui pengaruh model pembelajaran guided inquiry terhadap hasil belajar peserta didik yang dikhususkan pada materi sistem saraf manusia. Hasil peneliltian menunjukkan ada pengaruh model pembelajaran guided inquiry terhadap hasil belajar peserta didik pada materi sistem saraf manusia di kelas XI MIPA SMA Negeri 1 Sindangkasih.

Temuan pada penelitian ini menunjukkan bahwa model pembelajaran guided inquiry dapat meningkatkan hasil belajar peserta didik terutama pada dimensi kognitif C2 (memahami) dan C3 (mengaplikasikan).

\section{Saran}

penerapan proses pembelajaran menggunakan model pembelajaran Guided Inquiry mampu meningkatkan hasil belajar peserta didik; untuk penelitian selanjutnya, diharapkan dalam penerapan model pembelajaran Guided Inquiry; dan untuk peneliti selanjutnya, diharapkan mampu menerapkan model pembelajaran Guided Inquiry terhadap materi lain.

\section{UCAPAN TERIMA KASIH}

Penulis mengucapkan terimakasih kepada orang tua dan keluarga atas dukungan baik moral maupun materil dalam penelitian ini dan terimakasih juga kepada ibu Purwati Kuswarini Suprapto dan ibu Liah Badriah sebagai pembimbing dalam penelitian, serta penulisan artikel ini. 


\section{DAFTAR RUJUKAN}

Amijaya, L.S., Agus, R., \& I Wayan, M. (2018). Pengaruh Model Pembelajaran Inkuiri Terbimbing terhadap Hasil Belajar dan Kemampuan Berpikir Kritis Peserta Didik. J. Pijar MIPA. 13(2). 94-99.

Badriah, L. (2016). Perbedaan Hasil Belajar Dan Kemampuan Berpikir Kritis Mahasiswa Pendidikan Biologi Menggunakan Pendekatan Pembelajaran Deduktif Dan Induktif Pada Konsep Ekosistem. Bioedusiana, 1(1), 53-64.

Bagiarta, I. N., I Wayan, K., \& I Nyoman, S. (2015). Komparasi Literasi Sains Antara Siswa yang Dibelajarkan dengan Model Pembelajaran Kooperatif Tipe GI (Goup Investigation) dan Model Pembelajaran Inkuiri Terbimbing (Guided Inquiry) Ditinjau dari Motivasi Berprestasi Siswa SMP. E-journal Program Pascasarjana Universitas Pendidikan Ganesha, 5. 1-11. Dahar, Ratna Wilis. (2001). Teori-teori Belajar. Jakarta: Penerbit Erlangga.

Iswatun, I., Mosik, M., \& Bambang, S. (2017). Penerapan Model Pembelajaran Inkuiri Terbimbing untuk Meningkatkan KPS dan Hasil Belajar Siswa SMP Kelas VIII. Jurnal Inovasi Pendidikan IPA. 3(2). 150-160.

Ngasarotur, Laela., \& Partono. (2015). Pengaruh Model Pembelajaran Inkuiri Terbimbing Terhadap Hasil Belajar Fisika Siswa Kelas VIII SMP Negeri 4 Metro Semester Genap Tahun Ajaran 2013/2014. Jurnal Pendidikan Fisika Universitas Muhammadiyah Metro. 3(1). 64-72.

Nurfausiah., \& Suhardiman. (2016). Pengaruh Model Pembelajaran Inkuiri Terbimbing terhadap Hasil Belajar. Jurnal Pendidikan Fisika. 4(2). 10-13.

Nurdiansyah, \& Fahyuni, E. (2016). Inovasi Model Pembelajaran. Sidoarjo: Nizamial Learning Center. Sugiyono. (2017). Metode Penelitian Kuantitatif Kualitatif dan R\&D. Bandung: Alfabeta.

Taofiq, M., Dadi, S., \& Gito, H. (2018). Analisis Implementasi Model Pembelajaran Inkuiri dan Problem Based Learning Terhadap Kemampuan Literasi Sains Biologi Ditinjau dari Kemampuan Akademik yang Berbeda di SMAN 1 Kayangan. Prosiding Seminar Nasional Pendidikan Biologi.

Yani, A., Ruhimat, M. (2018). Teori dan Implementasi Pembelajaran Saintifik Kurikulum 2013. Bandung: PT Refika Aditama 